\title{
Drinking Water Quality Risk Management Risck Analysis of Nitrogen Groundwater Contamination Using Analytica Software
}

\begin{abstract}
ALICE IORDACHE, ALEXANDRU WOINAROSCHY*
University Politehnica of Bucharest, Romania, Department of Chemical and Biochemical Engineering, 1-7 Polizu Str., 011061, Bucharest, Romania

Drinking water supply is essential for public health, quality of life, sustainable development of economic activity, and environmental protection. In this context, it is important to ensure continuous improvement of all stages of processes to guarantee water quality and safety [1]. The main objectives of the study are: - development of an integrated method and probable risk analysis for a drinking water supply system; - risk assessment of contamination of raw water with nitrate [2].
\end{abstract}

Keywords: water quality risk analysis, water quality monitoring, Analytica software

Developing technical knowledge and growing concerns about public health and the environment contribute to positive developments in the water sector in many countries [1].

The management of drinking water quality management is based on the identification of hazards, risks, their analysis, of the probability of occurrence and the importance of potential consequences. The principles of the Food Safety Management System (which is a preventive risk management system) are based on the application of a method that priorities the hazards and risks and sets out the necessary control measures to reduce them to an acceptable level [3-4].

Water supply systems are vulnerable and subjective to a wide range of risks. The description of the water supply system analysis process should include all steps from the raw water source to the consumer's tap, including treatmenttechnology. Such an approach requires elements that are capable of shaping interactions between different events [2].

Water supply systems can be described as a series of steps to be taken to obtain safe drinking water in accordance with current legal regulations. To respect the safety of drinking water quality, each step requires careful management that includes:

-Monitoring and control of water sources;

-Appropriate water treatment and monitoring prior to distribution;

-Water storage and provision of water for consumers;

- Safe water distribution through proper maintenance of the distribution system;

-Monitoring the quality of drinking water distributed to consumers [3].

\section{Risk approach}

The risk can be defined as the probability that a specific unwanted event occurs with a certain periodicity or in specific circumstances. Thus, risk analysis is a combination of the following items, which must contain the following:

- probability of occurrence of an undesirable event (danger, accident);

- the severity of the consequences of this event [5].

The risk can be classified as follows:

- Qualitative: negligible, small, medium, large, serious.
- Semi-qualitative, when the elements of the risk (event probability and its consequences) are defined qualitatively, but together they provide quantitative risk values that allow hierarchy of the stages of unwanted events;

- Quantitatively, by measurable/ numerical evaluation of the probability function of the occurrence (frequency) of an unw anted event, as well as measurable indicators of the potential consequences of such an event [6].

\section{Case Study}

Description of Mangalia water supply system

Mangalia is a tourist town and a port on the Black Sea, situated near the southern end of the Romanian seaside.

At present, Mangalia has a centralized drinking water supply system consisting of groundwater sources Albesti, Vartop, Tatlageac, Dulce-ti and Pecineaga, water supply networks, Mangalia Storage and Pumping Complex, Tatlageac Storage and Pump Complex and distribution networks.

The Albesti water supply has 16 wells, with depths between $50-100 \mathrm{~m}$, with a capacity of $2310 \mathrm{~m}^{3} / \mathrm{h}(641.6 \mathrm{l} /$ s).

The Vartop source mainly provides the water supply of the Albesti village. If the water demand of Mangalia is high, the Vartop water source complements the need for pumped water in the village. The Vartop catchment area is located northwest of Albesti and consists of 5 wells (P1 P5) with depths of 50-160 m. The installed catchments rate is approx. $140 \mathrm{l} / \mathrm{s}$.

The captured water from the Vârtop and Albe-ti sources is disinfected in the Mangalia Pumped Storage Complex with chlorine at a dose of $0.5 \mathrm{mg} / \mathrm{L}$.

The Tatlageac source has a number of 6 wells drilled at depths between $50 \mathrm{~m}$ and $60 \mathrm{~m}$ and has a capture capacity of $705 \mathrm{~m}^{3} / \mathrm{h}(195 \mathrm{l} / \mathrm{s})$.

The Dulcesti source supplies Dulcesti with water and the surplus is directed to the Tatlageac Complex, adding water to the city of Mangalia. The source has a number of 13 wells drilled at depths between $56 \mathrm{~m}$ and $80 \mathrm{~m}$ and has a capture capacity of $625 \mathrm{~m}^{3} / \mathrm{h}(173.6 \mathrm{l} / \mathrm{s})$.

The Pecineaga source has a number of 11 wells drilled at depths between $73 \mathrm{~m}$ and $113 \mathrm{~m}$ and has a capture capacity of $634 \mathrm{~m}^{3} / \mathrm{h}(176 \mathrm{l} / \mathrm{s})$.

The captured water from Tatlageac, Dulcesti and Pecineaga sources is disinfected in the Tatlageac Pump Station with chlorine at a dose of $0.5 \mathrm{mg} / \mathrm{L}$ [ 7]. 


\section{Flow diagram}

An important aspect when analyzing the risks of drinking water systems is that the entire water supply system, from the water source to the consumer's tap, must be considered. This means that the water supply as well as the disinfection / treatment system and the distribution system to the consumer's tap must be taken into account.

The main elements for adopting an integrated strategy are:

- the existence of interactions between stages/ events (flow diagrams);

- the failure at one stage of the system can be offset by other steps / events.

If these items are not taken into account, important information can be overlooked.

In order to adopt an integrated strategy, there must be the possibility to compare the contribution of all stages to risk in order to avoid failure to choose the right solution for risk reduction [2].

The water supply system is commonly described as a supply chain composed of three main subsystems/ steps: raw water capture, treatment/ disinfection and drinking water distribution. Together, these subsystems/ stages cover the entire supply chain, from the water source to the consumer's tap. Throughout the supply chain there are risks that can affect the system in different ways.

Dangerous events may occur and their consequences are quantitative or qualitative. This means the inability to provide drinking water to consumers or the quality of the water itself is affected. The objective of the water supply system is to produce an adequate and continuous supply of drinking water which is chemically, bacteriological and organoleptical acceptable [2].
Figure 1 shows a Flow Diagram for the Mangalia Water Supply System. Drinking water distributed in the Mangalia Village comes from the underground sources of Albesti, Vartop, Tatlageac, Dulcesti and Pecineaga. The water disinfection system is made with chlorine, and water quality monitoring is done both the source (raw water), at the tank and in the distribution network (drinking water).

\section{Risk analysis}

In order to keep the risk at an acceptable level, it is essential to analyze the risk based on the level of risk identified and the causes of its occurrence to establish security actions to reduce it [2].

Risk analysis involves taking into account the causes and sources of risk, the severity of the potential consequences as well as the likelihood of their occurrence.

Table 1 lists the scale of the severity of the potential consequences and likelihood of occurrence of the consequences of an unwanted event with a certain periodicity or under certain circumstances [5].

Table 2 shows the level of risk expressed in terms of the combination of the consequences and their likelihood of occurrence.

The method of identifying the level of risk [10] (depending on severity and probability of occurrence) is as follows:

$$
N R=P . G
$$

Table 3 describes the risk classes, and the actions to be taken depending on the level of risk identified.

Table 4 presents the risk analysis of nitrate contamination at the Mangalia water supply system.

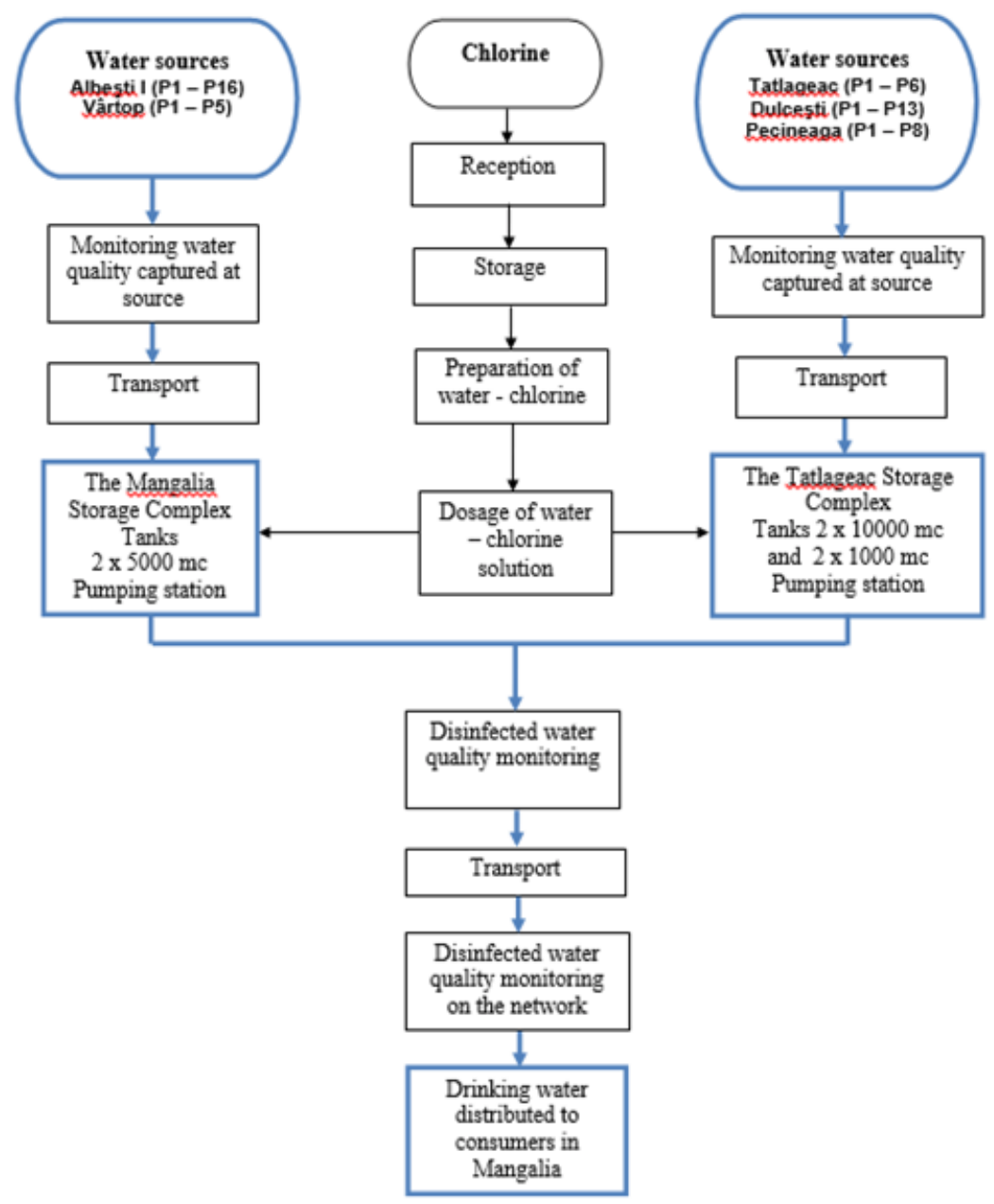

Fig. 1. Flow diagram of Mangalia Water Supply System 


\begin{tabular}{|c|c|c|c|c|c|c|c|}
\hline \multicolumn{3}{|c|}{ GRAVITY(G) } & \multicolumn{5}{|c|}{ GRAVITY OF POTENTIAL CONSEQUENCES } \\
\hline 1 & \multicolumn{2}{|c|}{ NEGLIGIBLE } & \multicolumn{5}{|c|}{ Consequences: no impact } \\
\hline 2 & \multicolumn{2}{|l|}{ SMALL } & \multicolumn{5}{|c|}{$\begin{array}{l}\text { Consequences: minor lesions and/or sickenings, the absence of effects or } \\
\text { minor effects, or consequences that appear only after exposure to high } \\
\text { value doses in long periods of time }\end{array}$} \\
\hline 3 & \multicolumn{2}{|l|}{ MEDIUM } & \multicolumn{5}{|c|}{ Consequences: minor diseases } \\
\hline 4 & \multicolumn{2}{|l|}{ LARGE } & \multicolumn{5}{|c|}{ Consequences: substantial prejudice and/or rarely serious disease } \\
\hline 5 & \multicolumn{2}{|l|}{ SERIOUS } & \multicolumn{5}{|c|}{$\begin{array}{l}\text { Consequences: fatal, serious diseases, incurabile prejudice, that manifest } \\
\text { themselves immediately or after a long period }\end{array}$} \\
\hline \multicolumn{3}{|c|}{$\begin{array}{l}\text { PROBABILITY OF } \\
\text { APPEARANCE (P) }\end{array}$} & \multicolumn{5}{|c|}{ PROBABILITY OF APPEARANCE OF CONSEQUENCES } \\
\hline 1 & \multicolumn{2}{|c|}{ VERY RARE } & \multicolumn{5}{|c|}{ Negligible: $\mathrm{P}<1 /$ year } \\
\hline 2 & \multicolumn{2}{|l|}{ RARE } & \multicolumn{5}{|c|}{ Small: $\mathrm{P}=1 /$ year } \\
\hline 3 & \multicolumn{2}{|c|}{$\begin{array}{l}\text { MODERATE } \\
\text { PROBABILITY }\end{array}$} & \multicolumn{5}{|c|}{ Medium: $\mathrm{P}=1 /$ month } \\
\hline 4 & \multicolumn{2}{|c|}{ PROBABLE } & \multicolumn{5}{|c|}{ Large: $\mathrm{P} \geq 1 /$ month } \\
\hline 5 & \multicolumn{2}{|c|}{ FREQUENT } & \multicolumn{5}{|c|}{ Serious: $\mathrm{P}>1 /$ week } \\
\hline \multicolumn{3}{|c|}{ Gravity (G) } & \multicolumn{5}{|c|}{ Risk level (RL) } \\
\hline \multicolumn{3}{|c|}{ Serious } & 5 & 10 & 15 & 20 & 25 \\
\hline \multicolumn{3}{|c|}{ Large } & 4 & 8 & 12 & 16 & 20 \\
\hline \multicolumn{3}{|c|}{ Medium } & 3 & 6 & 9 & 12 & 15 \\
\hline \multicolumn{3}{|c|}{ Small } & 2 & 4 & 6 & 8 & 10 \\
\hline \multicolumn{3}{|c|}{ Negligible } & 1 & 2 & 3 & 4 & 5 \\
\hline \multicolumn{3}{|c|}{$\begin{array}{l}\text { Probability of appearance } \\
\text { (P) }\end{array}$} & Very rare & Rare & $\begin{array}{l}\text { Moderate } \\
\text { probability }\end{array}$ & Probable & Frequent \\
\hline \multicolumn{2}{|c|}{ Risk level(RL) } & & & & class (RC) & & \\
\hline & $1-2$ & No action & equired & & & & \\
\hline & $3-5$ & Keep und & observation $/ \mathrm{c}$ & der the & source contro & vater treatme & easures \\
\hline & $6-10$ & $\begin{array}{l}\text { It is neces } \\
\text { is necesse }\end{array}$ & $\begin{array}{l}\text { ary to control th } \\
\text { if the treatmen }\end{array}$ & not app & or the treatm & rocess / a po & intervention \\
\hline & $12-16$ & $\begin{array}{l}\text { Emergenc } \\
\text { appropria }\end{array}$ & control of wate & stractio & eatment and i & ment if treat & is not \\
\hline & $20-25$ & $\begin{array}{l}\text { Emergend } \\
\text { appropria }\end{array}$ & control of wate & stractio & eatment and $\mathrm{i}$ & ment if treat & not \\
\hline
\end{tabular}

Table 1

GRAVITY OF POTENTIAL CONSEQUENCESAND PROBABILITY OF APPEARANCE OF CONSEQUENCES
Table 2

RISK LEVEL [5]
Table 3

RISK CLASS [5]
Analysis of the risk of contamination of raw water with nitrates using Analytica Software

Analytica offers an integrated risk and sensitivity analysis for uncertainty-entry models and powerful facilities for time-dependent dynamic simulations.

The shape of a node indicates the class of the variable or other object. In the model presented we used:

- General variable (a rounded shape with a thin contour): it can be uncertain because it depends on one or more random variables,

- Chance variable (an oval): Describes an uncertain quantity whose definition contains a probability distribution,

- Index variable (a parallelogram): defines the category along the size of a matrix,

- An objective variable (hexagon): describes an amount that evaluates the relative value, the likelihood or utility of possible outcomes,
- Decision variable (one square): it is directly under the control of the decision maker [9].

The main objectives of the study are:

(1) development of an integrated method and probabilistic risk analysis for a drinking water supply system;

(2) risk assessment of contamination of raw water with nitrate.

The analysis includes situations where the amount of water required for the consumer is delivered, but there is a risk that it does not meet the drinking water quality standards (failure to ensure the optimum quality of drinking water) [2].

Drinking water distributed in the Mangalia water supply system comes from the underground sources Albesti, Vartop, Tatlageac, Dulce-ti and Pecineaga.

The risk of nitrate contaminated underground water is due to the inappropriate disposal of waste. A potential 
Table 4

RISK ANALYSIS OF WATER CONTAMINATION WITH NITRATES AT THE LEVEL OF THE MANGALIA WATER SUPPLY SYSTEM

\begin{tabular}{|c|c|c|c|c|c|c|c|c|c|}
\hline $\begin{array}{c}\text { Potential } \\
\text { Risk }\end{array}$ & $\begin{array}{c}\text { Causes of risk } \\
\text { appearance }\end{array}$ & $\begin{array}{c}\text { Potential } \\
\text { consequences }\end{array}$ & G & $\mathbf{P}$ & RL & Security measures & $\begin{array}{c}\text { Residual RI } \\
\text { proposed }\end{array}$ & Responsabile & $\begin{array}{c}\text { Risk } \\
\text { reevaluation } \\
\text { term }\end{array}$ \\
\hline \multicolumn{10}{|c|}{ PROCESS: Capture and transport of raw water } \\
\hline \multicolumn{10}{|c|}{ Stage: Capture and transport of groundwater } \\
\hline $\begin{array}{l}\text { Underground } \\
\text { groundwater } \\
\text { contaminated } \\
\text { with nitrates } \\
{[8]}\end{array}$ & $\begin{array}{l}\text { - Inappropriate } \\
\text { disposal of } \\
\text { waste [5] }\end{array}$ & $\begin{array}{l}\text { - Contamination } \\
\text { of raw water [5] }\end{array}$ & 3 & 5 & 15 & $\begin{array}{l}\text { Monitoring the quality of raw } \\
\text { water } \\
\text { Stopping water supply from } \\
\text { contaminated drilling and } \\
\text { exclusive water supply from } \\
\text { uncontaminated drilling } \\
\text { - Stopping water supply if total } \\
\text { source contamination is found } \\
\text { and an imminent epidemiological } \\
\text { risk } \\
\text { - Informing authorities and } \\
\text { population } \\
\text { Training and awareness of ataff } \\
\text { [5] }\end{array}$ & 6 & $\begin{array}{l}\text { Workstation Chief } \\
\text { Manager } \\
\text { Laboratory [5] }\end{array}$ & $\begin{array}{l}\text { The end of the } \\
\text { current year [5] }\end{array}$ \\
\hline
\end{tabular}

consequence of this risk is the contamination of raw water, and the security actions that can be taken are: monitoring raw water quality, stopping contaminated drilling and feeding from uncontaminated drilling, stopping of water supply where the total contamination of the source is found, information to authorities and population, training and awareness of staff.

Figure 2 presents the diagram of the Analytica software on the evolution of the nitrate indicator at the Mangalia Water Supply System.
Water storage is provided in a tank of 10000 cubic meter ( 2 cuvettes of 5000 cubic meters) at the Mangalia Complex, one 20000 cubic meters ( 2 cuvettes of 10000 cubic meters) and a tank of 2000 cubic meter ( 2 cuvettes of 1000 cubic meters ) at the Tatlageac Complex.

According to census and exploitation data, the population served by the Mangalia water supply system is shown in Table 5. It can be seen a significant decrease in the number of users over the last 2 years.

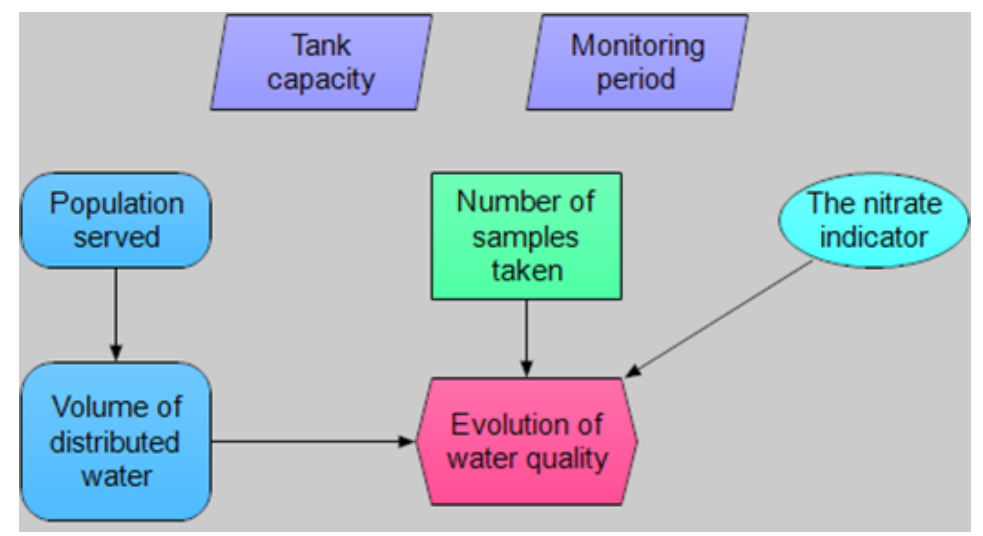

Fig. 2. Analytica chart for the evolution of the nitrate indicator

Table 5

EVOLUTION OF THE POPULATION SERVED, THE VOLUME OF DRINKING WATER DISTRIBUTED,

THE NUMBER OF SAMPLES TAKEN AND THE NITRATE INDICATOR FOR A PERIOD OF 5 YEARS

\begin{tabular}{|c|c|c|c|c|}
\hline YEAR & $\begin{array}{c}\text { POPULATION } \\
\text { PROVIDED } \\
\text { (number of users) }\end{array}$ & $\begin{array}{c}\text { VOLUME } \\
\text { WATER } \\
\text { DISTRIBUTED } \\
\left(\mathbf{m}^{3} / \text { day }\right)\end{array}$ & $\begin{array}{c}\text { NUMBER OF } \\
\text { ANNUAL } \\
\text { SAMPLES }\end{array}$ & $\begin{array}{c}\text { NITRATE } \\
\text { INDICATOR (mg/ L) }\end{array}$ \\
\hline 2014 & 41770 & 7820 & 19 & 47 \\
\hline 2015 & 41980 & 7405 & 14 & 44 \\
\hline 2016 & 41980 & 8405 & 36 & 42 \\
\hline 2017 & 36400 & 8348 & 19 & 41 \\
\hline 2018 & 33310 & 8355 & 15 & \\
\hline
\end{tabular}


The population served (number of users) of the Mangalia Water Supply System over a 5-year monitoring period is shown in Figure 3.

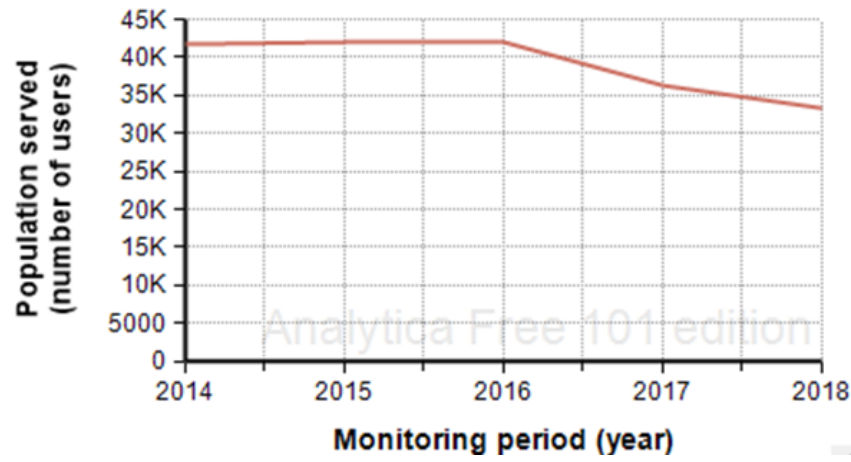

Fig. 3. Population served (number of users) over a 5-year monitoring period in the Mangalia Water Supply System

Figure 4 shows the evolution of the volume of water distributed over a 5-year monitoring period in the Mangalia Water Supply System.

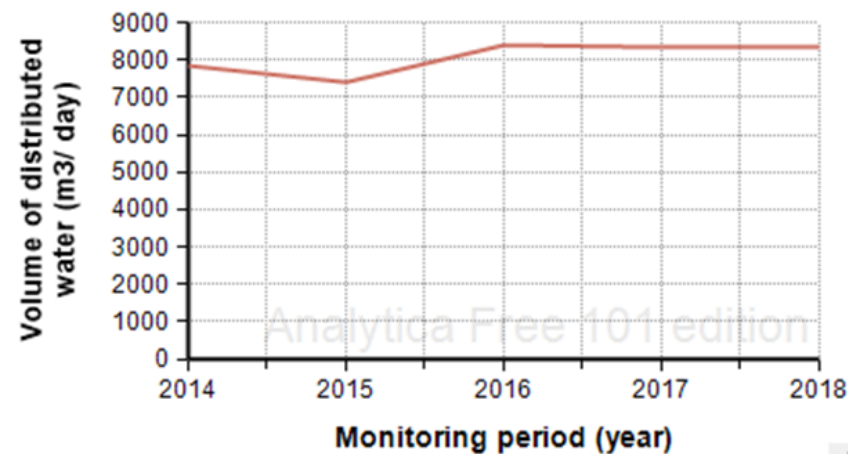

Fig. 4. Volume of water distributed over a 5-year monitoring period in the Mangalia Water Supply System

The number of samples taken annually for the nitrate indicator is established at the beginning of each year according to the evolution of the indicator in the previous year and is presented in Table 5 and Figure 5.

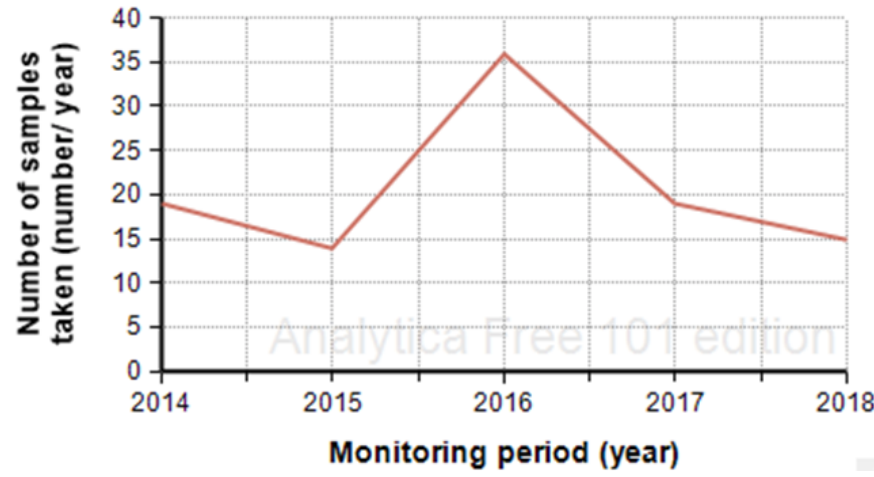

Fig. 5. Number of samples taken over a period of 5 years from the supply area of Mangalia Food Supply System

Figure 6 and Table 5 shows the evolution of the nitrate indicator for a period of 5 years. According to Law 458/ 2002, the maximum allowed value of the nitrate chemical parameter is $50 \mathrm{mg} / \mathrm{L}$.

Figure 7 shows the water quality trend for the nitrate indicator over a 5-year monitoring period at the Mangalia Water Supply System. An evolution of the nitrate indicator is quite noticeable in the year 2015.

The concentration and frequency of the presence of a contaminant in water are important and necessary to

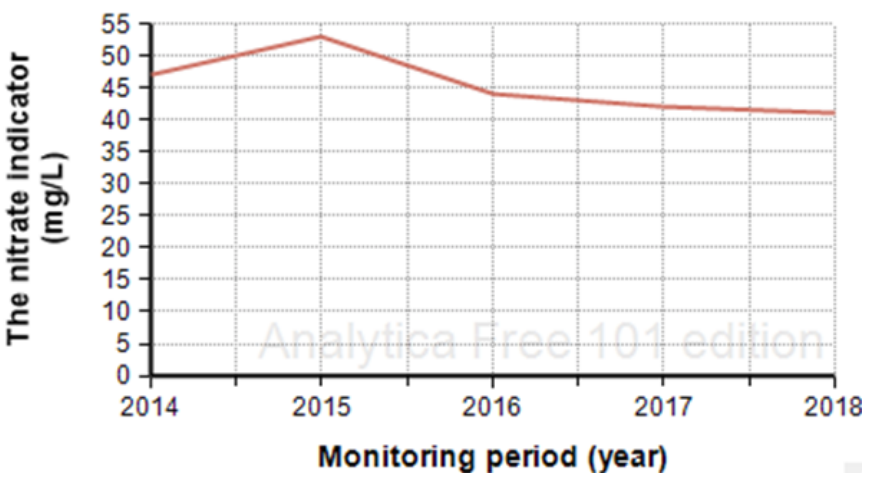

Fig. 6. Evolution of the nitrate indicator ( $\mathrm{mg} / \mathrm{L}$ ) over a 5-year monitoring period in the Mangalia Water Supply System

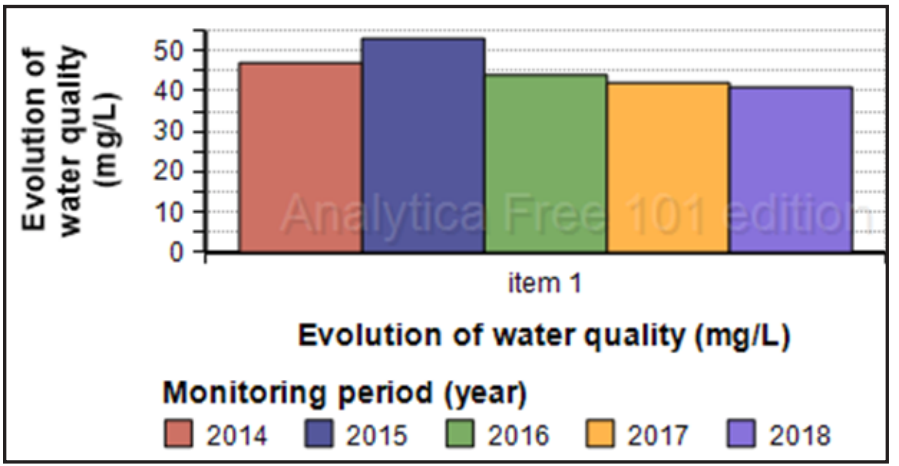

Fig. 7. Evolution of water quality over a 5-year monitoring period in the Mangalia Food Supply System

evaluate the health risk. Where there are exceedances of legal limit values, risk assessment is required to determine the security actions to be taken to reduce it. This is an important step because it is necessary to find a compromise between the provision of chemically contaminated water at values higher than the Maximum Admissible Concentration (CMA) and the risk of not distributing water or using alternative sources that may be microbiologically inappropriate [10].

Thus, once the maximum admissible limit has been exceeded, the water sampling system for monitoring the nitrate indicator has been intensified, the supply of water from the contaminated source has ceased and water has been supplied from the chemically appropriate sources of water.

\section{Conclusions}

Drinking water quality can be kept under control by combining the protection of raw water sources, controlling disinfection / treatment processes and managing the water distribution system.

There is a wide range of chemical and microbiological contamination agents that may be present in drinking water, some of which can adversely affect consumer health. Contaminants can come from a range of sources, and in some cases from the actual treatment process. Understanding the nature of hazards, sources of contamination and how they can enter the water supply system is an important aspect in achieving sanogenic and clean drinking water quality.

The most advantageous and effective means of producing safe drinking water is the application of risk management, supported by proper monitoring of the functioning of the supply system. As each stage of the water supply system can be susceptible to contamination, it is important that risk management represents a permanent approach throughout the water supply chain, from the raw water source to the consumer's tap. 
Drinking water quality assurance systems furthermore ensure that distributed drinking water is of good quality, is consistently provided and is made whenever significant improvements are needed in the water supply system, in resource/ investment management by implementing a water safety plan, water quality risk management [10].

Good communication throughout the technological flow is essential to ensure that all significant hazards and risks to the quality of drinking water quality are adequately identified and controlled. This involves both internal communication and external communication (with customers, suppliers of products and services, and authorities).

The established security actions must have a clearly defined monitoring regime that validates efficiency and monitors performance against established limits.

In this case study the Analytica software was exposed to analyze the evolution of the nitrate indicator at Mangalia city level.

The presented analysis can allow water operators to understand probabilities and potential impacts on water resources. It can be used as input for managementanalysis and for the analysis of emergency procedures for contamination of nitrate water.

\section{References}

1. ROEGER, A., TAVARES,A.F., Utilities Policy 53, 2018, p. 15.

2. LINDHE, A., ROSEN, L., NORBERG,T., BERGSTEDT, O., Water Res. 43, 2009, p. 1641.

3. *** Good Practice Guide to the Operation of Drinking Water Supply Systems for the Management of Microbial Risk, Final Report -WaterRA Project 1074, Water Research Australia Lmtd 2015, p. 3.

4.*** ISO 22000:2018 - Food safety management systems -Requirements for any organization in the food chain, p. 12.

5. WOINAROSCHY, A., IORDACHE, A., U.P.B. Sci. Bull 81 (1), 2019 , p.3.

6. G. MARIA, Evaluarea cantitativa a riscului proceselor chimice si modelarea consecintelor accidentelor, Ed. Printech, 2007, p. 21.

7.*** Memoriu tehnic - Sistemul de alimentare cu apa Mangalia, RAJ A S.A. Constana, 2018, p. 1.

8. CAVALIEREA, A., MAGGIB, M., STRFFOLINIC, F., Water Res. and Economics, 2017, p. 2

9. *** Lumina Decision Systems, Analytica Tutorial, 2015, p. 28.

10. *** www.particip.gov.md/public/documente - Guidance for the development of water safety plans, p. 13 - last access on 23.03.2018.

Manuscript received: 4.02 .2019 